\title{
Halkla İlişkilerde Kişisel Etki Modeli: Halkla İlişkiler Akademisyenlerinin Model Üzerine Değerlendirmeleri*
}

\author{
Pinar GÜNER KOÇAK** (D) \\ Mustafa AKDAĞ $\breve{H}^{* *}$ (i)
}

\begin{abstract}
ÖZ
Kișisel Etki modeli, birincil paydaş olarak adlandırılan kamu görevlileri, eski bürokratlar, söz sahibi gazeteciler, sivil toplum kuruluşu yöneticileri, aktivistler yani kısacası toplumda söz sahibi kimselerle halkla ilişkiler uygulayıcılarının iyi ilişkiler kurması, kurumun ihtiyacı olduğunda da bu ilişkilerden faydalanılarak halkla ilişkiler faaliyetlerinin başarılı bir şekilde yürütülmesi olarak tanımlanabilmektedir. Bu kapsamda yürütülen kişisel etki uygulamaları ise, misafirperverlik ilişkileri, ağırlama, önemli günlerin kutlanması, hediyeleșme ilișkilerinin yürütülmesi, birincil paydaşlarla ilgili düzenli ve güncel bilgi edinilmesi olarak sını flandırılabilir. Türkiye'de kişisel etki modeli ile ilgili çalışmalara bakıldı̆̆ında literatürün oldukça sınırlı olduğu görülmektedir. Halkla ilişkilerde kişisel etki modelinin uygulamalarına yönelik halkla ilişkiler akademisyenlerinin değerlendirmeleri araştrmanın konusunu oluşturmaktadır. Bu makalede kişisel etki modelinin Türkiye'de uygulanıp uygulanılmadığının belirlenmesi ve uygulanıyorsa nasıl uygulandığının tespit edilmesi amaçlanmıştır. Çalışma kapsamında yarı yapılandırılmıss mülakat soruları kattlımcılara e-posta yoluyla iletilmiş ve yanıtlar e-posta yoluyla toplanmıştır. Araștırmada görüșülen akademisyenler, olasılıksız örneklem kapsamında kota örnekleme ve amaçsal örnekleme tekniklerine göre seçilmiştir. Araştrma kapsamında 41 iletissim fakültesinden 21 akademisyenle görüşülmüştür. Akademisyenlerin halkla ilişkiler bölümlerinde çalışmasına dikkat edilmiştir. Sonuç olarak akademisyenlerin görüssleri değerlendirildiğinde, kişisel etki uygulamalarının Türk kültürü ve dinamikleri ile uyumlu olduğu ifade edilebilir. Türk kültüründeki misafirperverlik ilișkileri, imkanlar dâhilinde en ivi koșullarda ağırlamak, mutlu ve memnun avrılmalarını sağlamak, kişisel ilișki modelindeki misafirperverlik ilișkileri ile örtüşmektedir.

Anahtar Kelimeler: Kișisel Etki Modeli, Kişisel Etki Modeli Uygulamaları, Türkiye’de Kișisel Etki Modeli
\end{abstract}

\section{Personal Influence Model in Public Relations: Evaluations of Public Relations Academicians on The Model}

\begin{abstract}
The personal influence model can be defined as establishing good relations between public officials, former bureaucrats, journalists who have a say, NGO executives, activists called primary stakeholder,in short, public relations practitioners who have a say in the society and successfully conducting public relations activities by benefiting from these relations when the institution needs it. Personal influence practices carried out in this context can be classified as hospitality relations, hosting, celebration of important days, conducting gift relations, and obtaining regular and up-to-date information about primary stakeholders. Considering the work related personal influence model in Turkey it is seen that literature is quite limited. Evaluations of Public Relations Academics regarding the applications of the personal influence model in public relations are the subject of this research. In this article, it is aimed to determine whether the personal impact model is applied in Turkey and to determine how it is applied if it is applied. Within the scope of the study, semi-structured interview questions were sent to the participants via e-mail and their answers were collected via e-mail. The academics interviewed in the study were selected according to the quota sampling and purposeful sampling techniques within the scope of the improbable sampling. 21 academics from 41 communication faculties were interviewed within the scope of the research. Attention has been paid to the work of academics in public relations departments. As a result, when the opinions of academics are evaluated, it can be stated that the practices of personal influence are compatible with Turkish culture and dynamics. Hospitality relations in Turkish culture, welcoming them in the best possible conditions, making them happy and satisfied when leaving overlap with hospitality relationships in the personal relationship model.
\end{abstract}

Keywords: Personal Influence Model, Personal Influence Model Application, Personal Influence Model in Turkey

\section{Giriş}

Halkla ilişkilerde başarlı olmanın ön koşulu faaliyet gösterilen toplumlarda yürütülen iletişimden geçmektedir. Gerek birincil amacı topluma hizmet etmek olan kamu kuruluşları, gerek ana amacı kar etmek olan özel sektör işletmeleri, gerekse kamu yararını temel amaç edinen sivil toplum kuruluşları için

\footnotetext{
* Bu çalışma "Halkla İlişkiler ve Kültür İlişkisi Bağlamında Kişisel Etki Modeli Üzerine Bir Çalışma" isimli doktora tezinden üretilmiştir.

** Öğretim Görevlisi Dr., Nevşehir Hacı Bektaş Veli Üniversitesi, guner@nevsehir.edu.tr

*** Prof. Dr. Erciyes Üniversitesi, makdag@erciyes.edu.tr

Makale Gönderim Tarihi: 28.10.2020, Makalenin Kabul Tarihi: 25.11.2020
}

doi: 10.52642 /susbed. 898731 
hem kurum dışı hem de kurum içi kurulan iletişim oldukça önemlidir. Halkla ilişkiler bu iletişimin ana hatlarını belirlemektedir (Arklan, 2011, s. 17). Halkla ilişkiler uzmanları ya da uygulayıcıları hem iç hedef kitleleri ile hem de dış hedef kitleleriyle kurdukları ya da kuracakları iletişimin ana hatlarını belirlerken kamularının yaşayış tarzlarını, inançlarını yani kültürünü de dikkate almak zorundadırlar.

Kurumlann/kuruluşlanın, faaliyet gösterdikleri toplumlann kültürlerini bilmeleri, değer yargılarına göre hareket etmeleri, bu topluluklara sundukları hizmetler çerçevesinde elde ettikleri kazançları yine içinde bulundukları toplumların gelişmesi için harcamaları gerekmektedir. Kurumlar bu sayede hem gelişmekte ve kar elde etmekte hem de toplumun gelişimine destek olmaktadır. Bu noktada halkla ilişkiler, kurumlar ve toplum arasındaki bir katalizör görevi görmektedir. Ancak halkla ilişkiler faaliyetlerinin başarılı olması, toplum tarafından onaylanması, kabul edilmesi ve benimsenmesi için faaliyet gösterilen toplumun ve faaliyet gösteren kurum ya da kuruluşun kültürünü yakından tanımak gerekir.

Kültürün halkla ilişkiler faaliyetlerinde belirleyici bir etken olduğunun anlaşılmasının ardından benzer kültürlere sahip toplumlardaki halkla ilişkiler uygulamalarının sınıflandırılarak modelleştirilmesi, halkla ilişkilerde mükemmellik arayışını ve beraberinde halkla ilişkilerde etnosentrizm anlayışını getirmiştir. Halkla ilişkilerde etnosentrizm anlayışı ile bir ülkede yapılan bütün halkla ilişkiler faaliyetlerinin Dünyadaki tüm ülkelerde uygulanabileceği inancı ortaya çıkmışır. Grunig ve Hunt'un halkla ilişkiler modellerini gruplandırıp, mükemmellik teorisi için belirledikleri nitelikler buna verilebilecek en önemli örneklerdendir. Ancak özellikle kültür üzerine yapılan araştırmalar ve farklı ülkelerde karşılaştırmalı yürütülen halkla ilişkiler faaliyetleri neticesinde farklı bulguların elde edildiği görülmüştür. Bu farklılıklar içerisinde kanaat önderlerinin, kişisel ilişkilerin ve referans gruplarının halkla ilişkilerde belirleyici olabileceğini gösteren araştırmalar ortaya koyulmuştur. Sriramesh ve arkadaşlarının 1999 yılında Hindistan, Japonya ve Güney Kore'de yapmış oldukları çalışmalar, halkla ilişkiler faaliyetlerinde ve bu faaliyetlerin neticesinde hedef kitlelerine etki edebilmede farkllılklar olduğunu ve yürütülen halkla ilişkiler faaliyetlerinin ülkelerde farkllık gösterdiğini ve özellikle Hindistan'da yapılan çalışmalar neticesinde Sriramesh'in ortaya koyduğu "kişisel etki" modelinin halkla ilişkiler faaliyetlerinde belirleyici olduğu sonucuna ulaşmıştır (Sriramesh, Kim \& Takasaki, 1999, s. 285).

Bu kapsamda bu araştırmanın konusu, halkla ilişkilerde kişisel etki modelinin uygulamalarının halkla ilişskiler akademisyenleri görüşleri açısından değerlendirilmesi olarak belirlenmiştir. Temel amacı ise, kişisel etki modelinin Türkiye'de uygulanılıp uygulanılmadığının belirlenmesi ve uygulanıllyorsa nasıl uygulandığının tespit edilmesidir. Bu amaçla oluşturulan temel araştırma sorusu da, kişisel etki modeli uygulamalarının halkla ilişkiler faaliyetlerine etkisinin tespit edilmesi amacıyla sorulmuştur.

Literatür incelendiğinde kişisel etki modeliyle ilgili Türkiye'de doğrudan halkla ilişkiler faaliyetlerini inceleyen kapsamlı bir çalışma olmadığı görülmüştür. Bu çalışma kapsamında elde edilen veriler, kişisel etki modeli ile yürütülecek diğer araştırmalara ışık tutması açısından büyük önem taşımaktadır. Araştırma kapsamında 41 iletişim fakültesinden 21 akademisyenle görüşülmüştür. Araştırmada görüşülen akademisyenler, olasılıksız örneklem kapsamında kota örnekleme ve amaçsal örnekleme tekniklerine göre seçilmiştir. Akademisyenlerle uzman görüşme analizi ve yarı yapılandırılmış mülakat tekniği kullanılarak betimleyici bir çalışma yapılmışır. Akademisyenlerin halkla ilişkiler bölümlerinde çalışmasına dikkat edilmiştir. Çalışmanın sadece devlet üniversitelerinde çalışan akademisyenlerle sınırlandırlması ve e-posta yoluyla görüşmelerin gerçekleşmesi çalışmanın sınırlılıklarını oluşturmaktadır.

\section{Kişisel Etki Modeli}

Kişisel etki modeli ilk olarak J. Grunig, L. Grunig, K. Sriramesh, Y.H. Huang ve A. Lyra tarafindan yazılan (1995) "Models of Public Relations in an International Setting" isimli çalışmayla ortaya çıkmıştır. Bu çalşsmada, Hindistan, Yunanistan ve Tayvan'da yürütülen halkla ilişkiler faaliyetlerinin Grunig ve Hunt tarafından sınıflandırılan halkla ilişkiler modellerine uygunluğu ölçülmeye çalışılmıştır. Araştırmacıların her biri bu çalışma öncesinde kendi ülkelerinde yürütülen halkla ilişkiler faaliyetlerini belirlemek üzere nitel ve nicel çalışmalar yapmış ve sonrasında çalışmalarını bir araya getirerek bir meta analizi ortaya koymuşlardır.

$\mathrm{Bu}$ üç ülkenin seçilmesinin nedeni halkla ilişkiler araştırmalarının genel-geçer kabul edilen ama hep Anglo kültürüne sahip ülkelerde yürütülen halkla ilişkiler araştırmalarının uluslararası alanda ve farklı kültürlerde elde edilen sonuçlarını benzerlikler ve farklılar açısından değerlendirmektir (Akdağ \& Güner Koçak, 2018, s. 18). Araştırma neticesinde halkla ilişkiler uygulayıcılarının, profesyonel halkla ilişkilerin 
değerlerine ve hedeflerine attfta bulunsalar da, çoğunun bu değer ve hedeflere ilişkin uygulama bilgisi olmadığı tespit edilmiştir. Araştırmacılar halkla ilişkiler uygulamalarında da özellikle Anglo kültürü dışındaki ülkelerde iki farklı parametre ile karşılaştıklarını belirtmişlerdir. Grunig ve Hunt'un modelleri dışında ortaya çıkan bu iki ek uygulama modeli, "kişisel etki ve kültürel yorumsamacı model" olarak adlandır1lmıştır (Grunig, Grunig, Sriramesh, Huang \& Lyra,1995, s. 179-180). Hindistan'daki halkla ilişkiler faaliyetleri "kişisel etki" modeline, Yunanistan'dakiler ise "kültürel yorumsamacı" modelin uygulamalarına denk düşmektedir. Kişisel etki modelinin verilerine araştırmalardaki nitel verilerle ulaşılmıştır.

Makalede kişisel etki modeli şu şekilde ele alınmıştır: Örgütün halkla ilişkiler uzmanlarının, söz sahibi gazetecilerle, hükümette çalışan kamu görevlileri, eski diplomatlar, aktivistler, stk sorumluları vb. ile olan sıkı ilişkilerinin halkla ilişskiler faaliyetlerine olumlu etkileri olarak tanımlamışlardır. Çalışma kapsamında üç ülkedeki uygulayıcılar, kilit kişilerle ilişkilere, kendilerinden iyilik talep edilebilecek "temaslar" olarak değinmişlerdir (Grunig vd., 1995, s. 180). Kişisel etki modeline göre halkla ilişkiler uygulayıcıları medya ilişsilerinde gazetecilerle kurumları ya da faaliyetleri hakkında olumlu haber ya da hikayeler yazabilmeleri için bağlantı kurmaktadır. Bu açıdan değerlendirildiğinde kişisel etki modeli basın ajansı modeline benzemekle birlikte, basın ajansı modelinde dikkat çekmek için şişirilmiş ve şaşalı olaylar ve fotoğraflar verilmekteyken, kişisel etki modelinde sadece gerçek olaylar hakkında sadece kişisel ilişkilere odaklanılarak haber ve duyurma yapıldığının altı çizilmektedir.

Sriramesh kişisel etki modelini, sadece önemli noktalardaki kilit insanlarla kurulan iyi diyaloglar olarak ele almamakta aynı zamanda misafirperverlik ilişkilerini de bu modelin bir tekniği olarak tanımlamaktadır. Ağırlama ilişskilerinin genel amacı, önemli karar alma noktalarında gazeteciler veya diğer kilit noktalarda faaliyet gösteren bireylerle kalıcı bir ilişsi kurmaktır. Ağırlama ilişkileri yürüten halkla ilişkiler uygulayıcıları, bağlantı kurulmak istenen kimselere hediyeler vererek, öğle yemeği veya akşam yemeği organizasyonları gerçekleştirerek bu kimselerin takdirini kazanmakta ve gerektiğinde organizasyon adına iyilik istemek için önemli bir kanalı açık tutmaktadırlar (Grunig vd., 1995, s. 180). Kişisel etki modeline göre, halkla ilişkiler uzmanları uzun vadede örgütlerinin çıkarları için yetkili ve söz sahibi kimselerle ve örgütlerle yakın ilişki kurmalı, önemli günleri hatırlamalı, hediyeleşmeli, davetler düzenlemeli ve misafirperverliğini göstermelidir. Uzun vadede örgütün ihtiyacı olduğunda yardım isteyebileceği bu nüfuzlu kişi ve kuruluşlarla kişisel ilişkilerini kurabilmeli ve etkiyi arttırmalıdır.

Halkla ilişkilerin kişisel etki modelini işlevsel hale getiren üçlü etkileşim, halkla ilişkiler uygulayıciları ve onların temel paydaşlarının profesyonelleşmiş etkileşim kurallarını öğrenmeleri ve uygulamaya koymaları için bir çerçeve oluşturmaktadır. Etkileşimin kuralları, kültür, politik iklim, profesyonel roller ve etkileşim halindeki bireylerin sosyal statüsü gibi çeşitli faktörlere bağlı olarak farklılık göstermektedir (Schriner, 2008, s. 4). Bu sebeple doğru ve profesyonel bir etkileşim kurabilmesi için halkla ilişkiler uygulayıcılarının eğitim almış ve toplumun seçkinleri arasında yer alan kişilerden seçilmeleri gerekir. Böylece bu uygulayıcılar, kilit bireylerle kişisel temaslarda rahatlıkla kendi seviyelerinde sosyal ilişkiler kurabileceklerdir.

Kişisel etki modeline göre sadece kişisel ilişkiler ve misafirperverlik ilişkilerinin profesyonel ve stratejik bir şekilde yürütülmesinin dışında örgüte zararı dokunabilecek kimseler, organizasyonun rakiplerinin kimler olduğu, toplumda belirleyici olabilecek kanaat önderleri, piyasa da etkili köşe yazarları, topluma yön veren önemli şahıslar vb. hakkında detaylı güncel veriler toplanmalıdır.

Kişisel etki modelinin halkla ilişkilerin beşinci modeli kabul edilmesi ve özellikle kültür unsurunu ön plana çıkarması birçok araştırmacı tarafından farklı ülkelerde bu modelin sınanmasını sağlamıştır. Ancak yapilan çalışmaların çoğunlukla Asya ülkelerinde kümelenmesi zamanla eleştiri unsuru olarak değerlendirilmiştir. Ayrıca bu modelin uygulamalarının farklı kültürlere sahip ülkelerde de mevcut olabileceğine yönelik araştırmalar da yapılmıştır. Kişisel etki modelini geliştirmek için yöntemsel olarak çok sayıda nitel ve nicel araştırma yapılmasına karşın, bu modelin olumsuz özelliklerini vurgulayan, etik olmayan uygulamaları vurgulayan eleştirel çalışmalar da yapılmıştır (Akdağ \& Güner Koçak, 2018, s. 19).

\section{Kişisel Etki Modeli Uygulamaları}

Grunig, Grunig, Sriramesh, Huang and Lyra'nın (1995) farklı kültürleri karşılaştırmaları üzerine Hindistan'da uygulanan halkla ilişkiler yöntemlerini tanımlamak üzere ortaya çıkan kişisel etki modeli, uygulamaları bağlamında Asya kültürlerinde önemli bir karşsllk bulmuştur. Bunun en temel sebebi, 
kültürün halkla ilişkiler faaliyetlerinde belirleyici kabul edilmesi, bireysel ilişkilerin ve kültürel ritüellerin toplumsal hayatın dışında örgütsel yapıyı da şekillendirmiş olmasıdır.

Akdağ ve Güner Koçak; kişisel etki modeli üzerine yapılan araştırmalarda bu modelin uygulamalarının kimi araştırmacılar tarafından misafirperverlik, karşıllklı iyi ilişkiler olarak değerlendirilse de kimileri tarafından da etik dışı faaliyetler ya da bu faaliyetleri olumlayıcı ifadeler olarak eleştirildiğini belirtmektedir. Bu görüş farklılıkları ülkelerden ülkelere ve kültürlerden kültürlere değişmektedir. Bu nokta da kişisel etki kuramının öncüleri de toplumsal kültür ve örgüt kültürü arasındaki bağlantıyı iyi anlamak gerektiğinin ve yürütülen halkla ilisskiler faaliyetlerinde toplumsal kültürün onayının önemli olduğunun defalarca altını çizmişlerdir (2018, s. 34).

Kişisel etki modelinin uygulamalanı, halkla ilişsiler uzmanlarının, kilit paydaş olarak adlandırılan söz sahibi gazetecilerle, hükümette çalışan kamu görevlileri, eski diplomatlar, aktivistler, stk sorumlularıyla olan sıkı ilişkilerinin halkla ilişkiler faaliyetlerine olumlu etkileri olarak yansıması amacıyla yürüttükleri birincil ilişkileri, önemli gün kutlamalarını, davetler düzenleme ya da kilit paydaşların davetlerine katılımı, hediyeleşme ilisskilerini, misafirperverlik (ağırlama) ilişkilerini kapsamaktadır. Bunların dışında örgüte zararı dokunabilecek kimseler, organizasyonun rakiplerinin kimler olduğu, toplumda belirleyici olabilecek kanaat önderleri, piyasa da etkili köşe yazarları, topluma yön veren önemli şahıslar vb. hakkında detaylı güncel veriler toplanması da bu uygulamalar içerisinde değerlendirilebilir.

\section{Halkla İlişkiler Akademisyenlerinin Kişisel Etki Modeli Üzerine Değerlendirmeleri}

Türkiye'de kişisel etki modeli ile ilgili literatür tarandığında alanda sadece iki çalsşmanın olduğu görülmektedir. İlk çalışma Becerikli'nin "Uluslararası Halkla İlişkiler Eğitiminde Yeni Bir Bakış Açısı: Kişisel Etki ve Kültürel Yorumsamacı Modelin Katkıları Üzerinden Türkiye'deki Alan Müfredatlarına İlişkin Bir Değerlendirme” (2008) isimli çalışmasıdır.

Türkiye'de yapılan ikinci çalışma ise Akdağ ve Güner Koçak'ın "Bibliometric Analysis on Personal Influence Model as Public Relations Model” (2018) isimli çalışmadır. Akdağ ve Güner Koçak, uluslararası literatürde kişisel etki modeli ile ilgili yapılan çalışmaların ele aldığı konuları, modelin eleştirildiği noktaları ve kişisel etki modeliyle ilgili sonrasında yapılabilecek çalışmalar için bir bibliyometrik analiz yapmışlardır.

Sriramesh'in "kişisel etki” kuramı, halkla ilişkiler uygulamalarında ülkelerin kültürlerinin etkisini gözler önüne sermektedir. Halkla ilişkiler, ister kurum içinde olsun ister kurum dışında olsun gerek toplumun kültüründen etkilenmekte, gerekse örgüt kültürüyle toplumsal kültüre etkide bulunabilmektedir. Türkiye, coğrafi ve kültürel özellikler bakımından 7 bölgeye ayrılmıştır. Bu 7 bölge de kendi içerisinde farklı kültürel özellikler taşımaktadır. Türkiye'nin kültürel zenginliği, insan ilişkilerine ve iletişimine de yansımaktadır. Halkla ilişkiler çalışmaları da bu kültürel özelliklere göre şekillenmektedir. Bu çalışma, Türkiye'deki halkla ilişkiler akademisyenlerinin bilgi birikimlerinden faydalanılarak, kişisel etki modelinin halkla ilişkiler faaliyetlerinde kullanılıp kullanılmadığının tespit edilmesi yönelik genel bir görüşün ortaya koyulması açısından önem taşımaktadır.

Nitel yöntemlerde en yaygın kullanılan veri toplama tekniklerinden birisi mülakatlardır. Mülakatlar da kendi içerisinde gruplara ayrılmaktadır. Yapılandırılışlarına göre, felsefi ve disipliner yönelime göre ve odak grup görüşmeleri olarak sınıflandırılabilmektedir. Yapılandırılışlarına göre mülakatlar; tam yapılandırılmış, yarı yapılandırılmış ve yapılandırılmamış mülakatlar olmak üzere de kendi içerisinde ayrılmaktadır. Tam yapılandırılmış mülakatlarda sorular ve soru sayıları önceden belirlenerek, demografik değişkenler hakkında bilgi toplanmak amaçlanır. Yarı yapılandırılmış mülakat soruları özellikleri itibariyle diğer mülakat türlerine göre daha esnek bir yapıya sahiptir, katılımcılardan spesifik verilerin toplanması amaçlanır ve görüşmenin büyük bir kısmı açıklığa kavuşturulması istenen sorulardan oluşur. Yapılandırılmamış mülakatlar ise, açık uçlu sorulardan oluşan, esnek ve açıklayıcı olan, araştırmacının araştırma yaptığı fenomen hakkında detaylı bilgisinin olmadığı ve temel amacın daha sonraki görüşmeler için sorular hazırlamayı öğrenmek olduğu mülakat türüdür (Merriam, 2017, s.87-91).

Görüşmelerin yürütüleceği kişiler de belirli kriterlere göre değerlendirilmektedir. Görüşülmek istenen kişiye göre görüşmeler; önderler, uzmanlar ve halk ile yapılanlar olmak üzere üçe ayrılmaktadır. Önderlerle yapılan görüşmeler, genellikle geniş kitleleri ilgilendiren belli konularda oluşan ana görüşlerin ve sorunların ortaya çıkarılması ya da belli bir araştırma için izin alma vb. amaçlarla yapılır. Uzman kişilerle yapılan 
görüşmelerde, belli uzmanlık alanlarında, ayrıntılı teknik bilgi toplanır. Halk ile yapılan görüşmelerde ise, belli konularda genel bilgi, tutum ve davranışların öğrenilmesi amaçlanır (Karasar, 2019, s. 212).

Çalışma kapsamında, Türkiye'de halkla ilişkiler alanında eğitim veren akademisyenlerin algılarını, deneyimlerini, bilgi birikimlerini birinci ağızdan elde edilen veriler çerçevesinde anlamlandırmak amacıyla uzman görüşme analizi ve yarı yapılandırılmış mülakat tekniği kullanılarak betimleyici bir araştırma yapılmıştr. Bu çalışmada evren, Türkiye'de faaliyet gösteren 41 üniversitenin iletişim fakültelerinde halkla ilişkiler ve tanıtım/ halkla ilişkiler ve reklamcılık/ reklamcllık ve halkla ilişkiler bölümlerinde görev yapan, akademik ünvanı Profesör, Doçent, Doktor Öğretim Üyesi ve ders verme yeterliliğine sahip olan akademisyenlerden oluşmaktadır.

2019 verilerine (YÖK, 2019) göre Türkiye'deki devlet üniversiteleri iletişim fakültelerinde 76 Profesör Doktor, 92 Doçent Doktor, 84 Doktor Öğretim Üyesi ve 27 Öğretim Görevlisi bulunmaktadır. Araştırmada görüşülen akademisyenler, olasılıksız örneklem kapsamında kota örnekleme ve amaçsal örnekleme tekniklerine göre seçilmiştir. Olasılıksız örnekleme tekniğinde, örneklem kapsamında araştırlacak olan birimler, araştırmanın amacına uygun olarak, belirli kriterler göz önünde tutularak kasıtlı olarak seçilmektedir (Taylan, 2015, s. 74). Kota örneklemede araştırmacının araştırma evreninden belirli özellikleri, ortak özellikleri olanları gruplandırması ve bunlardan belli bir sayıya ulaşıncaya kadar örneklem almasıdır (Aziz, 2015, s. 54). Amaçsal örnekleme de araştırmacının edindiği bilgilere göre araştırmanın amacına en uygun olduğunu düşündügü̈, belirli yerler, kişiler ya da olayların kasıtlı olarak seçildiği örnekleme türüdür (Taylan, 2015, s. 79). Örneklemin bir araştırma için büyüklüğü dikkate alındığında ise, Creswell nitel araştırmalarda belirlenen örneklem büyüklüğünün araştırmanın doğasına bağlı olduğunu belirtmektedir. Creswell gözden geçirdiği pek çok nitel araştırmaya göre, anlatı araştırmalarında bir veya iki, fenomenoloji üç ile on, kuram oluşturma yirmi ile otuz kişiyi incelemeyi içerebileceğini belirtmektedir. Verilerin doygunluğa ulaşmasının yani verilerin toplanmasıyla ilgili yeni bakış veya özellikler ortaya çıkmadığında veri toplama sürecinin sonlandırılabileceğini belirtmektedir (2017; s. 189). Araştırma kapsamında 41 iletişim fakültesinden 21 akademisyenle görüşülmüştür. Akademisyenlerin halkla ilişkiler bölümlerinde çalışmasına dikkat edilmiştir.

$\mathrm{Bu}$ çalışma kapsamında verilerin güvenilirliği ve geçerliliğini sınamak adına akran değerlendirilmesi yapılmıştr. Halkla ilişkiler alanındaki akademisyenlere sorular önceden gönderilerek anlaşılır olup olmadığ1 sınanmıştır. Ardından sorulanın konuyu detaylıca ele alıp almadığının belirlenmesi adına farklı üniversitelerden öğretim üyelerine danışllmış ve soruların daha anlaşılır hale getirilmesi sağlanmıştır. Örneklem seçiminde her üniversiteye ulaşılarak araştırma sahasının çeşitliliğinin yansıtılması amaçlanmıştır.

Betimsel türden bir analizin kullanıldığ bir araştırmada görüşülen bireylerden doğrudan alıntılara yer vermek ve bunlardan yola çıkarak sonuçları açıklamak geçerlik için önemli olmaktadır (Yıldırım \& Şimşek, 2018, s. 270). Çalışma kapsamında katılımcıların görüşlerine doğrudan yer verilerek, elde edilen sonuçlar değerlendirilmiştir. Araştırma kapsamında katılımcılarla yapılan ilk görüşmede katılımcılara isteğe bağlı olarak isimlerine araştırmada yer verileceği ve istemeyenlerinde gerçek ad ve soyadlarına yer verilmeyerek "Katılımcı 1, Katılımcı 2 gibi” kodlamalar yapılabileceği belirtilmiştir. Görüşülen katılımcıların yarısının isimlerinin kullanılmamasını talep etmesi üzerine tüm görüşmeciler "Katılımcı 1-Katılımc1 2 vb." kodlarıyla değerlendirilmiştir. Görüşülen akademisyenlerin cinsiyet dağılımına bakıldığında 11 kadın, 10 erkek akademisyenden oluşan homojen bir dağılım bulunmaktadır. Ayrıca katılımcıların akademik unvanlarına bakıldığında 3 Prof. Dr., 12 Doç. Dr., 4 Doktor Öğretim Üyesi ve 2 öğretim görevlisi bulunmaktadır.

Çalışmanın bilimsel etiğe uygunluk belgesi Nevșehir Hacıbektaş Veli Üniversitesi Etik Kurul Komisyonundan 23.12.2020 tarihinde 2020.22.346 sayll karar ile alınmıştır.

\section{Bulgular ve Değerlendirme}

Kişisel etki modelinin uygulamaları çalışmanın literatür kısmında da tartışıldığı üzere, halkla ilişkiler uzmanlarının, kilit paydaş olarak adlandırlan söz sahibi gazetecilerle, hükümette çalışan kamu görevlileri, eski diplomatlar, aktivistler, stk sorumlularıyla olan sıkı ilişkilerinin halkla ilişkiler faaliyetlerine olumlu etkileri olarak yansıması amacıyla yürüttükleri birincil ilişkileri, önemli gün kutlamalarını, davetler düzenleme ya da kilit paydaşların davetlerine katılımı, hediyeleşme ilişkilerini, misafirperverlik (ağırlama) ilişkilerini kapsamaktadır. Bunların dışında, örgüte zararı dokunabilecek kimseler, organizasyonun 
rakiplerinin kimler olduğu, toplumda belirleyici olabilecek kanaat önderleri, piyasa da etkili köşe yazarları, topluma yön veren önemli şahıslar vb. hakkında detaylı güncel veriler toplanması da bu uygulamalar içerisinde değerlendirilebilir.

\subsection{Kilit Paydaşlarla İlişkiler}

Kişisel etki modelinde tanımlanan kilit paydaşlar, uzun vadede örgütün çıkarları için yardım talep edilebilecek nüfuzlu kimselerdir. Gazeteciler, hükümette çalışan kamu görevlileri, eski diplomatlar, aktivistler, stk sorumluları gibi kimselerden oluşmaktadır. $\mathrm{Bu}$ kilit paydaşlarla ilişkilerin kurulup, sürdürülebilmesi için halkla ilişkiler uygulayıcılarının önemli bir çaba sarf etmesi gerekmektedir. Kilit paydaşlarla ilgili önemli gelişmeleri takip etmek, düzenledikleri davetlere katılım (doğum, ölüm-taziye, evlilik seramonileri vb.), toplantılar, yemek ve gezi organizasyonları düzenlemek uygulayıcıların birincil ilişskiler kurması için gerekli faaliyetlerdendir. Bu bağlamda görüşmecilere halkla ilişkiler faaliyetlerinin başarısında kilit paydaşlarla birincil ilişki kurmanın önemi sorulmuştur. Görüşmecilerin tamamı "kilit paydaşlarla birincil ilişki kurmanın halkla ilişkiler faaliyetlerinde yadsınamaz bir öneminin olduğunu" belirtmişlerdir. Görüşmecilerden bir kısmı birincil ilişkileri kilit paydaşlarla oluşturulan güven temelli iletişim üzerinden ele almışlardır.

Bu kapsamda görüşmecilerden Katıllımc1 3, hedef kitlenin öncelikle güven duydukları kişilerin görüş ve fikirlerini dikkate alacaklannı ancak kilit paydaşlanın da güven duyulan kişiler içerisinde yer alabileceğini işaret etmektedir. Katılımcı 20'de, hedef kitlenin mesajları güvendikleri kişilerden almalarının mesajların etkisini arttıracağını ve bu sebeple birincil ilişki kurulan kilit paydaşlann ve kanaat önderlerinin halkla ilişkiler uygulamasının başarısını etkileyen önemli bir kriter olduğunu belirtmektedir. Katılımcı 10'da halkla ilişkiler de kurulacak ilişkilerde güven ve samimiyet unsurlarının alını çizmektedir.

Görüşmecilerden bir kısmı "kilit paydaşlar ve kanaat önderleri ile kurulan ilişkilerin kurumun itibarı için de önemli olduğunu" belirtmektedirler:

Katıllımc1 1, kanaat önderleri, bürokratlar ve gazetecilerin hedef kitleyle kurdukları sürdürülebilir iletişimin kurumun itibarı açısından da önemli olduğunu ve bu kilit paydaşlarla birincil ilişkiler kurmanın önemini vurgulamaktadır. Katılımcı 12'ye göre ise, bu kilit paydaşların kurumların etkinliklerinde yer almasının yürütülen uygulamanın haber değerini yükselterek böylece kurumun medyada görünürlügünü arttracaktır. Ayrıca kriz anlarında ilk ve doğrudan temas kurulabilmesi açısından önemli bir avantaj oluşturmaktadır. Katılımcı 15 tecrübelerinden yola çıkarak haber yayınlatabilmek, bilgi ya da belgeye ulaşmak için kilit paydaşlarla birincil ilişkiler kurmanın oldukça önemli olduğunu belirtmektedir.

Katıllımc1 14 ve Katılımc1 18, birincil paydaşlarla kurulan ilişkilere kuramsal açıdan yaklaşarak bir açıklama getirmiştir: Buna göre Katılımcı 14’ün belirttiği “iki aşamalı akış modelinde” toplumda güvenli ve saygideğer bir kişinin genellikle kanaat önderinin etkisinin ve "gündem belirleme modelinde" olduğu gibi insanların ne hakkında konuşacaklarına ve gerçekleri ne olarak düşüneceklerinin, kuracaklarının medya tarafından belirlenmesi açısından değerlendirildiğinde halkla ilişkiler uygulamalarının çıtıllanının haber olarak yayınlanması için ya da kuruma zarar verebilecek olumsuz bir bilginin ortadan kaldırılması için birincil ilişkilerin yürütüldüğü gazetecilerin ve editörlerin etkisi oldukça önemli olmaktadır. Benzer bir şekilde hedef kitlenin güvenini tesis etme noktasında iki aşamalı akış modelinde olduğu gibi kanaat önderleriyle işbirliğinin yapılması kurum ya da işletmeye olan bakış açısında etkili olacaktır. Katılımcı 18 kanaat önderleri, gazeteciler, hükümet yetkilileri, stk sorumluları, eski diplomatların birer eşik bekçisi olarak hedef kitle ile kurum, işletme arasında bir köprü vazifesi görerek ilişki ağlarını oluşturduklarını belirtmektedir.

Katılımcılardan bir kısmı "halkla ilişkiler uygulayıcılarının birincil hedef kitleyle ilişki kurulmasını kuruma ya da işletmeye sağlayacağı avantajlar çerçevesinde" değerlendirmiştir: Katıtlımcı 17 kurumun toplumsal meşruiyet elde etmesinde ve sürdürülmesinde birincil paydaşlarla uzun vadeli ve kalıc ilişkilerin kurulmasının öneminin altını çizmektedir. Katılımcı 8'e göre birincil ilişkiler sayesinde daha çok hedef kitleye ulaşmak söz konudur ve ayrıca kilit paydaşlarla ilişsi kurulmasıyla halkla ilişkiler faaliyetlerinin daha başarılı olacağını ifade etmektedir. 
Katılımc1 9 ise tarihsel olarak Türkiye'deki büyük işletmelerin/holdinglerin halkla ilişkiler müdürlerinin gazeteci temelli olduklarını ve bu kimselerin kuracakları birincil ilişkilerin stratejik bir öneminin olduğunu, işletmelerin o dönemlerde bu durumun farkında olduklarını belirtmiştir.

Görüşmeciler farklı açılardan yaklaşıp ele almalarına karşın her biri "halkla ilişkiler uygulamalarında birincil ilişkiler kurulmasının önemli olduğunu ve faaliyetlerin başarısını etkilediğini" belirtmişlerdir. Buradan yola çıkarak görüşmecilere, Türk toplumundaki halkla ilişkiler faaliyetlerinde kilit paydaşlarla birincil ilişki yürütülüp yürütülmediği sorulmuştur. Görüşmecilerin büyük bir çoğunluğu "halkla ilişkiler faaliyetlerinde kilit paydaşlarla birincil ilişkiler kurulduğunu" ifade etmişlerdir.

Katıllımc1 2 ve Katıllımc1 21, hedef kitleyle ilişki kurabilmenin temel koşulunun birincil ilişki kurmaktan geçtiğini belirtmekte, paydaşların kendilerine değer verildiğini hissetmek istediklerini ve birincil ilişkilerle samimiyetle daha iyi bir iletişimin kurulabileceğini ifade etmişlerdir. Görüşmecilerden bir kısmı (Katılımc1 4, Katılımcı 6, Katılımcı 8, Katıllımc1 19) kilit paydaşlarla birincil ilişki kurabilmek için kurumsallık ve profesyonelliğin gerekliliğinin altını çizmiştir.

Görüşmecilerin ifadeleri değerlendirildiğinde profesyonel, kurumsal, büyük olarak adlandırdıklant işletmelerin birincil ilişkileri daha küçük ve yerel işletmelere oranla daha iyi yürüttükleri kanaati ortaya çıkmaktadır. Katılımcı 4'ün belirttiği "bu işlerde başarılı olan", Kattlımcı 6'nın belirttiği "kurumsal işletmeler", Katıllımc1 8 'in belirttiği "bütçe olarak büyük kurum ve kuruluşlar" ifadeleri kilit paydaşlarla birincil ilişkiler kurmanın profesyonel olarak yürütülmesi gereken faaliyetler olduğunu işaret etmektedir. Katılımc1 19 ise, kilit paydaşlarla kurulan ilişkilerin örgütsel birçok kritere göre işletmelerden işletmelere farklılık gösterebileceğini belirtmektedir.

Görüşmecilerden bazıları “Türkiye'de yürütülen halkla ilişkiler uygulamalarında kilit paydaşlarla yeterince birincil ilişki kurulamadığını" belirtmektedir:

Katıllımc1 1 birincil ilişkilerin sadece kurumun faaliyetlerinde kurulduğunu ve onun ötesine gidemediğini belirtmekte ve yetersiz olduğunu ifade etmektedir. Katllımc1 17 bu konudaki yetersizliği eleştirmekte ve bu sebeple halkla ilişkiler alanının teknik bir uygulama alanına döndügünü belirtmektedir. Katıllımcı 17'ye göre halkla ilişkiler uygulamalarıyla medyada görünür olmak, kilit paydaşlarla birincil ilişki kurmaktan daha çok tercih edilmekte ve bu sebeple halkla ilişkiler teknik bir uygulama alanına dönüşmektedir. Katılımcı 11'de kurumların birincil ilişki kurmaktan özellikle gazetecilerin çıkarlarını gözetmek şeklinde algılandıklarını ve gazetecilerinde her şeyi bu sebeple gözardı edebileceğini sanıldıklarını belirterek aslında halkla ilişkiler uygulayıcılarının kilit paydaşlarla birincil derecede ilişki kurma konusunda yetersiz olduklarını vurgulamaktadır.

Katılımc1 14' de, Katılımc1 17'nin belirttiği Türkiye'de kilit paydaş olarak özellikle gazetecilerle ilişki kurulduğunu belirtmektedirler. Katılımc1 18 ise Türkiye'de halkla ilişkiler uygulamalarında kilit paydaşlarla birincil ilişkilerin yanlış ve etik olmayan yöntemlerle kullanılabildiğini belirtmektedir.

Benzer şekilde görüşmecilerin bir kısmı da (Katulımc1 9, Katılımcı 20, Katlımc1 12) halkla ilişkiler uygulamalarında kilit paydaşlarla birincil ilişkiler kurulabileceğini ancak bunun etik olmayan yöntemler çerçevesinde kullanılmasının yanlış olacağına dair endişelerini belirtmektedirler.

Görüşmecilerin etik olmayan unsurlarla ifade etmeye çalıştıkları, kilit paydaş olarak gruplandırllan kesimin tarafl, sübjektif, olayların üstünün örtülmesine destek veren, hatta katılımc1 18'in de belirttiği gibi halkla ilişkiler uygulamalarında araştırmaya, planlamaya ve uygulamaya yeterince önem vermeden doğrudan birincil ilişkilerle başarılı olma çabası olarak ifade edilebilir.

Kişisel etki modeli uygulamalarında belirleyici olan kilit paydaşlarla birincil ilişkiler, halkla ilişkiler faaliyetlerinin başarllı bir şekilde yürütülmesinde oldukça önemli bir unsurdur. Kişisel etki modeline göre halkla ilişkiler faaliyetleri sadece kriz dönemlerinde kurumla ilgili olumsuz bilgilerin düzeltilmeye çalışılması ve bu kapsamda kurumun kendi lehine haber yapılmasını kapsamamaktadır. Uzun vadede toplumda benimsenen, desteklenen ve örnek alınan, görüş ve fikirlerine önem verilen ve kilit paydaş olarak tanımlanan bu kimselerle kurum ve kuruluş ile ilgili uzun vadede temas kurulması, örgütün yürüttügü toplumsal, kültürel ve sosyal faaliyetlerde başarılı olmasına katkı sağlayacaktır. Kilit paydaşlarla birincil ilişkiler kurulması aynı zamanda kurumla ilgili olumsuz bir haber ortaya çıktığında doğrudan kuruma destek verecek taraftarların oluşmasını sağlayacaktır. Ancak bazı görüşmecilerin belirttiği gibi halkla ilişskiler faaliyetleri profesyonel bir şekilde yürütülmeden, halkla ilişkiler uygulayıcıları üstlerine düssen 
sorumlulukları yerine getirmeden bu birincil ilişkilere güvenerek medyada yer almak, hedef kitle de olumlu bir izlenim oluşturmaya çalışmak gibi çabalar hem kuruma hem de kilit paydaş olarak adlandırılan kimselere zarar verebilir.

\section{2. Önemli Günlerin Kutlanması, Davetler ve Hediyeleşme İlişkileri}

Kişisel etki modeline göre, kilit paydaşlarla birincil ilişkiler kurulmasının yanında önemli günlerin hatırlanması, hediyeleşmeler, davetler düzenlemek ve misafirperverlik ilişkileri yürütmek, rakipleri ve kamuoyunu araştırmak gerekmektedir. Önemli günlerin kutlanması, davetler ve hediyeleşme ilişkileri kilit paydaşlarla birincil ilişki kurulmasında önemli bir etkendir. Bu kapsamda görüşmecilere öncelikle halkla ilişkilerde bu faaliyetlerin yürütülmesinin ne ifade ettiği sorulmuştur. Görüş̧mecilerin tamamı önemli günlerin kutlanmasının, davetler ve hediyeleşme ilişkilerinin halkla ilişkiler faaliyetlerine olumlu bir etkisinin olacağını belirtmişlerdir. Görüşmecilerden bir kısmı "önemli gün kutlamalan1, davetler ve hediyeleşme ile gerek kurum içi çalışanlar gerekse hedef kitlenin önemsendiğini ve kendini daha değerli hissettiğini ve böylece daha sıcak ve samimi ilişkiler kurulabildiğini” belirtmektedir.

Katılımcı 1'e göre bu tarz uygulamalar, bütün hedef kitleyi kapsayıcı şekilde yürütülmelidir ve doğum günleri, hastalıklar, ölümler, insanlann acılarını paylaşma gibi olgular bireyleri daha değerli ve mutlu etmektedir. Katılımcı 20'ye göre bu etkinliklerle özellikle çalışanların motivasyonlanı ve aidiyet duyguları artmaktadır. Katılımcı 15, bu etkinliklerle ilişkilerin sıcak ve samimi tutulacağını belirtmektedir.

Önemli gün kutlamalan, davetler ve hediyeleşme ilişkileri aynı zamanda kurumsal iletişimin pekiştirilmesi, kurumsal kimlik ve imaj açısından da önemlidir: Bu kapsamda Katılımcı 2 bu uygulamaların yeterince iyi yönetilmediğini, halkla ilişkiler politikaları bağlamında hedef kitleyle iletişim kurulabileceğini ancak henüz o seviyede olunmadığını belirtmektedir. Katıllımc1 8, bu tarz etkinliklerle kurum kültünün pekiştirileceği, kurumun bilinirliliğinin arttırılarak kurum kültürüne ve imajına yönelik olumlu çıktılar elde edileceğini ifade etmektedir. Katılımcı 10 'da bu etkinliklerin kurumsal imaj ve itibar açısından önemli olduğunu belirtirken, Kattlımcı 6 ise paydaşlarla ilişkilerin olumlu yönde iyileştirilmesine ve bu ilişkilerin sürekliliğini sağlamasındaki etkilerine dikkat çekmektedir.

Katıllmc1 12 ise, bu etkinlikleri Türk kültürünün toplumsal ritüelleri olarak değerlendirmekte ve bu uygulamalara yüklenen anlamların toplumsal çevre, sosyo-kültürel yap1 gibi unsurlara göre farklılık gösterebileceğini vurgulamaktadır.

Görüşmecilerin bir kısmı, "önemli günlerin kutlanması, davetler ve hediyeleşme ilişkilerinin hem bireysel hem de kurumsal olarak sağlayacağı katkılar dışında, bu ilişkiler doğru ve dozunda ayarlanmazsa etik ile ilgili bir takım kaygıların ve problemlerin ortaya çıkabileceğini”' belirtmektedirler.

Katılımcı 3, bu ilişkilerin etik kuralların dışına taştığında ilişki kurulan insanların kaybedilmesi ve örgütsel amaçlar bağlamında etik kodların dışına çıkılmasına sebep olabileceğini; Katılımcı 9 kilit paydaşlarla özellikle hediyeleşme ilişkilerinin etik olmadığını çeşitli Stk ve derneklerin "iletişim ve medya ilişkileri yönetiminde mesleki ilkeler belgesi" olduğunu ve bu kapsamda "çıkar birliği oluşturma, ödüllendirme, rüşvet gibi unsurlardan” dolayı hediyeleşme ilişskilerinin yasak olduğunu ancak küçük çaplı hediyelerin bu yasak kapsamından çıkarıldığını belirtmektedir. Katılımcı 18 bu uygulamaların dozunun doğru ayarlanmadığını, Katılımcı 19 ise hediyeleşme ilişkilerinin, medya ile ilişkilerde manipülasyon amaçlı kullanılmaması gerektiğini ifade etmektedir. Katılımcı 21 ise hediyeleşme ilişkileri kapsamında kurum ya da kuruluşların büyük bütçeler harcayarak kuruma zarar vermemeleri gerekliliğini vurgulamaktadır.

Kişisel etki modeli ile ilgili eleştirel çalışmalar incelendiğinde hediyeleşme ilişkilerinin ve bu tarz uygulamaların rüssvet ve kayırma olarak değerlendirilebildiği görülmektedir (Akdağ \& Güner Koçak, 2018, s. 24-30). Ancak Türk kültüründe bakıldığında hediyeleşme kültürel bağlamda oldukça önemlidir. Doğumlarda (altın, bebek malzemeleri vb.), dügünlerde (altın, para, ev eşyaları vb.) hatta ölümlerde (yiyecek, içecek, çay, şeker vb.) bile sembolik hediyeler verilebilmektedir. Buradan da hediyeleşme ilişkilerinin farklı kültürlerde farklı açılardan değerlendirilebilmekte olduğu sonucu çıkmaktadır. Bu bağlamda görüşmecilere "Türk kültüründeki hediyeleşme ritüeli farklı toplumlarda nasıl değerlendiriliyor olabilir?” sorusu yöneltilmiştir. Görüşmecilerden bir kısmı (Katılımcı 18, Katılımcı 15, Katılımc1 7) Türk toplumundaki hediyeleşme ritüelinin farklı toplumlarda da benzer anlamlar taşıyacağı ve herhangi bir farkın olmayacağını belirtmişlerdir. 
Görüşmecilerden bir kısmı "hediyeleşme ilişkilerini, kültürel dinamikler ve inanç bağlamında" ele almıştır. Buna göre yapılan kıyaslamalarda, Batı toplumlarında kapitalist sistemin insanları tüketime yönlendirdiğini ve hediyeleşme ilişkilerinin metalarla değer aktarımı olarak geliştiği, ancak Türk toplumu ve Doğu toplumu olarak tanımlanan ve özellikle İslam dinine mensup toplumların hediyeleşme ilişkilerine zekat, sadaka ve sünnet bakış açısıyla yaklaştkklarını belirtilmektedir:

Katılımcı 1 ve Katılımc1 2 Batılı toplumların kapitalist yapıdan etkilendiğini ve bu durumun hediyeleşme ilişkilerini etkilediğini belirtmektedirler. Katılımcı 1'e göre Batılı toplumlar faydacı bakış açısına sahip olduklarını ve hediye olarak sunulan her şeyin tek bir anlamı ifade edeceği kanısında olduklarını ve hediye almaktan hoşlanırken karşıllğında hediye vermekten hoşlanmadıklarını belirtmektedir. Ancak Türk toplumunda ve daha Doğu’ya doğru gidildikçe özellikle inancın etkisiyle aile, değerler, sadaka gibi unsurların hala etkisini koruduğunu ifade etmektedir. Kattlımc1 2, Kattlımcı 1'den farklı olarak kapitalizmin tüm toplumları etkilediği ve günümüzde hediyeleşme ilişkilerinin birer gösteriye döndügünü, zekat olgusunun geçmişteki meşruiyet değerleri ile bugünkü değerlerin birbirinden farklı olduğunu belirtmektedir. Katılımc1 20, Batı toplumlarında hediyeleşme ilişkilerinin değer aktarımından ziyade nesnelerin değiş tokuşu haline geldiğini ama Türk ve Doğu kültürlerinde hediyeleşmenin akrabalık, bağllılı, aile olma duygularını yönlendiren ritüeller olarak korunduğunu belirtmektedir.

Katılımc1 12'de hediyeleşme ilişkileri açısından Türk toplumu ve Doğu toplumlarının benzerlik gösterdiğini, Batı toplumlarında ise hediyeleşmenin önemsenmediğini belirtmektedir.

Bu görüşlerin yanında katılımcılardan bir kısmı (Katılımc1 6, Katılımc1 9, Katılımc1 14) hediyeleşme ilişkilerinin farklı kültürlerde etik olmayan bir davranış olarak değerlendirilebileceği hatta rüşvet olarak alg1lanabileceğini ifade etmişlerdir.

Görüşmecilerin ifadeleri değerlendirildiğinde öncelikle kimlere hediye verileceği, bu kişilerle olan iliş̧inin yakınlık derecesi, alınacak kararlarda bu hediyeleşme ilişkilerinin etkisi gibi hususlara dikkat çekilmektedir. Ancak Katılımcı 6'nın belirttiği "hediyeleşme ilişkilerinin doğu kültürlerinde rüşvet olarak değerlendirilmesi” ifadesine bakıldığında, kişisel etki modeli ile yapılan çalışmalarda genellikle batı toplumlarında ve kültürlerinde kişisel etki modeline etik olamayan unsurlar (rüşvet, kayırmacıllk vb.) açısından yaklaşıldığı, Doğu toplumlarında ve kültürlerinde hediyeleşmenin gündelik hayat içerisinde yeri bulunan bir unsur olduğu hatta İslamiyet inancina göre de hediyeleşmenin dini bir ritüel olarak ele alınabileceğini belirtmek gerekir. Ancak hediyelerin maddi boyutu yükseldikçe etik olmayan davranışlara yönelik bu kaygılar ortaya çıkmaktadır. Bu doğrultuda görüşmecilere "verilen hediyelerin maddi boyutu ilişkilerin doğasını etkiler mi?” sorusu yöneltilmiştir. Görüşmecilerin büyük bir kısmı etkileyeceği kanaatindedir. Etkileyeceğini belirten görüşmecilerin bir kısmı olumsuz olarak etkileyeceğini, bir kısmı ise olumlu olarak etkileyeceğini belirtmiştir. Hediyelerin maddi boyutunun ilişkileri olumsuz bir şekilde etkileyebileceğini belirtenlerin üzerinde durdukları ilk husus bu hediyelerin rüşvet olarak algilanabileceği, diğer bir husus ise birincil ilişkilerin çıkar ilişkileri üzerine inşa edilebileceğine dair duydukları kaygıdır:

Katılımc1 2 ve Katılımc1 1 özellikle kamu kurum ve kuruluşlarında verilen hediyelerin maddi boyutlarının yüksek olması durumunda bunun rüşvet olarak algılanabileceğini ve sonrasında ilişkilerin sorunlu bir hal alabileceğini belirtmektedir. Katılımcı 20 ise medyanın insanlara değerli ürün hizmet kullandıklarında daha değerli olacaklarına dair düşünceleri empoze ettiği ve bu sebeple paydaşların yüksek maddi değere sahip hediyeler aldıklarında kendilerini iyi hissedebileceğini ve bu durumunda çıarc1 ilişkilerin ortaya çıkmasına neden olabileceğini belirtmektedir.

Katılımc1 20'nin görüşüne paralel olarak Katllımc1 12'de, medya ve iletişsim teknolojilerinin kişilere "kalabalıklar önünde daha görünür olma" görüşünü aşıladığı için kültürel değerlerde kırılmalar olduğunu ve verilen hediyelerin maddi boyutlanyla değerlendirilebileceğini belirtmektedir.

Görüşmecilerden bir kısmı ise "hediyelerin maddi boyutunun ilişkilerin doğasını olumlu etkileyeceği, hediyelerin maddi boyutu arttkça hediye alanlarnn daha değerli olduğunu ve önemsendiğini düşüneceği”" kanisindadir:

Katılımc1 19 özellikle Türk kültüründe hediyeleşmenin ihtiyaçları karşılama ve işlevsellik açısından ilerlediğini, kurumsal olarak da bu şekilde ilerleyebileceğini, Katllımc1 7 maddi boyutun ön planda olmadığını, Katıllımcı 5, hediyenin maddi boyutundan ziyade hediye verilecek kişinin bireysel özelliklerine göre verilen hediyelerin aidiyeti geliştireceğini, Katllımc 14 ise maddi değeri düşük bir hediye verildiğinde 
paydaşların kendilerine değer verilmiyor hissine kapılma riski olduğundan maddi boyutun ilişkiyi olumlu olarak etkileyebileceğini ifade etmektedir.

Görüşmecilerin bir kısmı (Katıllımc1 21, Katılımc1 18) ise "verilen hediyelerin maddi boyutundan ziyade manevi boyutunun daha değerli olabileceğì" kanaatindedir:

Katılımcı 21 verilen hediyelerin maddi değerlerinin yüksek olmasının paydaşlar tarafindan rüşvet olarak anlaşılabileceğini bu sebeple manevi değeri olan hediyelerin daha makul olacağını belirtmektedir.

Kişisel etki modeline göre kilit paydaşlarla birincil ilişkiler kurulması için önemli günlerin kutlanması, davetler ve hediyeleşme ilişkileri oldukça önemlidir. Fakat bu uygulamalar kültürlerden kültürlere farklı değerlendirilebilmekte ve bazı toplumlarda olağan karşılanan durumlar farklı toplumlar tarafindan olumsuz bir bakış açısıyla eleştirilebilmektedir. Özellikle hediyeleşme ilişkilerinin ve bu ilişkilerin maddi boyutunun halkla ilişkiler uygulamalarında etik olmayan davranışlara evrilmesi gibi bir problem ortaya çıkabilmektedir.

\subsection{Toplumsal Ritüeller ve Misafirperverlik İlişkileri}

Kişisel etki modelinin önemli uygulamalarından birisi de misafirperverlik/ ağırlama ilişkileridir. Ağıllama ilişkilerinin genel amacı, önemli karar alma noktalarında gazeteciler veya diğer kilit noktalarda faaliyet gösteren bireylerle kalıcı bir ilişki kurmaktır. Ağırlama ilişkileri yürüten halkla ilişkiler uygulayıcıları, bağlantı kurulmak istenen kimselere hediyeler vererek, öğle yemeği veya akşam yemeği organizasyonları gerçekleştirerek bu kimselerin takdirini kazanmakta ve gerektiğinde organizasyon adına iyilik istemek için önemli bir kanalı açık tutmaktadırlar (Grunig vd.,1995, s. 180). Misafirperverlik ilişkileri sadece bir halkla ilişskiler uygulaması olarak değil aynı zamanda toplumsal ve kültürel bir unsur olarak da değerlendirilebilmektedir. Türk kültürünün özellikleri değerlendirildiğinde misafirperver ve paylaşımcı bir yapısının olduğu bilinmektedir. Tarihteki Türk devlet yapısında görülen ahilik sistemi, kervansaraylar, hanlar hamamlar ve eski evlerdeki misafir odaları Türklerin misafirperverliğinin bir kanıtıdır (Toprak, 2019, s. 75). Bu kapsamda Türk kültüründeki toplumsal ritüellerin ve misafirperverlik ilişkilerin kişisel etki modelinin uygulamalaryyla örtüşüp örtüşmediğini değerlendirilmeye çalısılmıştır. Görüşmecilere ilk olarak Türk kültüründeki toplumsal ritüellerin (bayramlaşma, başarıların kutlanması için hediyeleşme vb.) halkla ilişkiler faaliyetlerini nasıl etkilediği sorulmuştur. Görüşmecilerden elde edilen veriler arasında en dikkat çekici yanıt Katılımc1 1'e aittir. Katılımc1 1, hediyeleşme ilişkilerinde belirttiği gibi Türk kültüründeki toplumsal ritüellerin belirlenmesinde inanç ve din faktörünün büyük rol oynadığını bu sebeple hediyeleşme, selamlaşma, ziyaretler vb. ritüellerin halkla ilişskilerde olumlu etkilerinin bulunacağını belirtmektedir.

Görüşmecilerin büyük bir kısmı "Türk toplumundaki kültürel ritüellerin halkla ilişkiler faaliyetlerine birçok açıdan olumlu etkilerinin olacağını” belirtmişlerdir:

Görüşmecilerden elde edilen veriler değerlendirildiğinde kültürel dinamikler aracillğgyla halkla ilişkiler faaliyetlerinde iki yönlü iletişim gerçekleştirilerek (Katıllmc1 4), iletişimdeki aksaklılar ortadan kaldırılabileceği, kültürel dinamikler aracıllğıyla faaliyet çeşitliliği artacağı gibi aidiyet bilinci ve örgütsel bağlılığın sağlanabileceği, kurum imajına olumlu etkide bulunacağı (Katllımc1 8, Katllımc1 16, Katlımc1 19), hedef kitleyle sürdürülebilir bir iletşşim kurup, muhafaza edileceği ve sosyal ilişskileri güçlendireceği (Katılımc1 12), ritüellerin etkinlik yönetimi kapsamında çeşitlilik sağlayacağı (Katılımcı 6, Katılımc1 14), paydaş ilişkilerinin yürütülmesine katkı sağlayacağı yönünde görüşler bulunmaktadır.

Görüşmecilerden bir kısmı, "Türk toplumunda kültürel ritüellerin halkla ilişkiler faaliyetlerine olumlu etkilerinin bulunmasının yanında bu ritüellerden bir ya da birkaçının yetersiz ya da amacı dışında uygulandığında ortaya çıkabilecek sıkıntılara" değinmiştir:

Bu kapsamda Katılımcı 2, kültürel ritüellerin halkla ilişskilerin etkinlikleri için uygun zemin hazırladığını ancak halkla ilişkiler uygulayıcılarının bu konuda yetersiz olduğunu belirtmektedir. Ona göre, özellikle hediyeleşme ilişkilerinde kamu alanında hediye alınıp verilecekse bunun başkaları tarafından rüşvet gibi etik dışı faaliyetler çerçevesinde değerlendirilebileceğine ve bunun kurumların ve hediye verilen kişilerin itibarlarında zedeleyici olacağına dair endişelerini dile getirmiştir. Katılımc1 9, kültürel dinamiklerin ilişkilere dinamizm getirdiğini ancak medya aracilığılla Türk kültürünün de kapitalist sistemden etkilendiğini ve bu ritüellerin anlam ve işlevlerinden sıyrılarak samimiyetsiz bir hal aldığını belirtmektedir. Katılımcı 20, kültürel ritüellere uygun davranılmasının halkla ilişkilerde başarı sağlayacağını fakat bu ritüellerin birer 
zorunluluk ve karşılıklılık olarak algılanmasının çeşitli sıłıntılar ortaya çıkarabileceğini ifade etmektedir. Katulımcı 18 ise özellikle hediyeleşme ilişkilerinde hediyelerin maddi boyutlarına dikkat edilmesi ve herkese hediye verilmemesi gerektiğini altını çizmektedir.

Görüşmecilere Türk toplumunun kültürel ritüellerinin halkla ilişkiler uygulamalarına etkisinin ardından, misafirperverlik ilişkilerinin halkla ilişkiler faaliyetlerine etkisi sorulmuştur. Bu bağlamda görüşmecilerden bir kısmı "Türk toplumunda misafirperverlik ilişkilerinin halkla ilişkilere sağladığ1 ya da sağlayacağ1 avantajlar üzerinden değerlendirme yapmış", bir kısmı ise "misafirperverlik ilişkilerinin nasıl olması gerektiğine dair görüşlerini” bildirmiştir. Görüşmeciler, misafirperverlik ilişkilerinin halkla ilişkiler uygulamalarına sağlayacağı avantajları farklı boyutlarıyla değerlendirmişlerdir. Katılımcı 2 misafirperverlik ilişkileriyle birincil ilişkilerin geliştirilebileceğini ve hedef kitleyle daha samimi bir iletişim kurulabileceğini belirtmektedir. Katılımc1 12'ye göre de misafirperverlik ilişkileri kilit paydaşların beklentilerine yön vermekte ve ayrıca yürütülen faaliyetlerde olumlu bir etki oluşturmaktadır.

Katılımcı 4, misafirperverlik ilişkileri ile halkla ilişkiler uygulamalarında güven ortamının yaratıldığını, Katılımcı 6, bu ilişkiyle halkla ilişkiler faaliyetlerinde sürekliliği olan sosyal etki yaratılabileceğini, Katılımc1 8, Türk insanının misafirperverliği ve diyalog kurmaktan çekinmeyen yapısı sayesinde iletişimde zorluk çekmeyeceğini ve bu durumun da halkla ilişkiler faaliyetlerine avantaj olarak yansıyacağını, Katılımc1 10 ise misafirperverlik ilişkileri ile farklı kültürler üzerinde olumlu bir imaj oluşturulabileceğine değinmişlerdir.

Görüşmecilerden bir kısmı "Türk misafirperverlik ilişkilerinin yürütülme biçimini ve halkla ilişkiler uygulamalarında etkilerini ele alarak açıklamışlardır”: Katılımcı 20 misafirperverlik ilişkilerinin halk kültürünün önemli değerlerinden biri olduğunu, saygı ve hoşgörü temeline dayandığını, misafiri rahat hissettirmenin, ikramların ve oluşabilecek yanlış anlaşılmaların önüne geçilmesinin önemini, halkla ilişkiler faaliyetlerinde de bu özenin gösterilmesinin gerekliliğini belirtmektedir. Katulımc1 21, misafirperverlik ilişkilerinde olduğu gibi basın toplantılarında, basın gezilerinde, bir konuşmacı davet edildiğinde halkla ilişkiler uygulayıcılanının aynı hassasiyetle davranması gerektiğini ifade etmektedir. Katılımcı 15'de benzer bir şekilde Türk kültüründe misafirlere gösterilen özenin halkla ilişkiler uygulamalarında gösterilmesi gerekliliğinin, misafirlerin isteklerine öncelik verilmesinin, misafirleri memnun etmenin her şeyden önce geldiğinin altını çizmektedir.

Misafirperverlik ilişkilerinin hediyeleşme ilişkilerinde olduğu gibi farklı boyutlara çekildiği ve a nlamının ve işlevinin farklılaştı̆̆ını bu sebeple samimi olmadığını belirten görüşmeciler de bulunmaktadır: Katılımcı 9, Türk kültüründeki misafirperverlik ilişkilerinin diğer kültürlere göre ayırt edici bir değer olduğunu fakat değişen toplum yapısı nedeniyle eskisi kadar yoğun sürdürülmediğini ve halkla ilişkiler bağlamında misafirperverlik ilişkilerinin çıkar temeline göre ilerlediğini ve bu açıdan halkla ilişkiler faaliyetlerinde misafirperverlik ilişkilerinin samimiyetsiz olduğunu belirtmektedir.

Kişisel etki modelinde, kilit paydaşlarla birincil ilişkiler kurmak, bu hedef kitleyle, önemli günlerin kutlanması, hediyeleşme ilişkileri, misafirperverlik/ağırlama ilişkilerini yürütmek gibi uygulamaların olduğunu belirtilmişti. Ancak kişisel etki modeli kapsamında misafirperverlik ilişkilerini değerlendirebilmek için sadece halkla ilişkiler uygulamalanı ile sınırlandırmak yanlış olacaktır. Çünkü halkla ilişkiler uygulamalarının hedef kitleleri faaliyetlerin amaçlarına göre farklı farklı olabilmektedir. Kişisel etki modelinin hedef kitlesi ise bir önceki bölümde tanımlandığı gibi kilit paydaş olarak tanımlanan gazeteciler, bürokratlar, kanaat önderleri, stk yöneticileri gibi gerek toplumda gerek bağlı bulundukları kurum ve kuruluşlarda söz sahibi kimselerdir. Sorunun amacına ulaşabilmesi için sadece Türk toplumunda halkla ilişkiler uygulamalarında misafirperverlik ilişkilerini kültürel bağlamda ele alınması yeterli olmadığı için görüşmecilere halkla ilişkiler uygulayıcılarının kilit paydaşlarla yürüttükleri faaliyetlerdeki misafirperverlik ilişkileri hakkındaki görüşleri sorulmuştur. Bu kapsamda görüşmecilerin büyük bir kısmı, "uygulayıcıların kilit paydaşlarla yürütülen misafirperverlik ilişkilerinin kurum açısından olumlu sonuçlarının olacağını" belirtmiştir. Ayrıca kilit paydaşlarla yürütülen misafirperverlik ilişkilerinde uygulayıcıların taşıması gereken nitelikleri ve kurulacak ilişki yapısı üzerinde yoğunlaşan veriler de bulunmaktadır: Kilit paydaşlarla yürütülen misafirperverlik ilişkileri hakkında Katılımc1 2, kurum adına savunucular elde edileceğini ve kurumsal itibar açısından da önemli olduğunu, Katılımcı 6 kilit paydaşların desteğinin alınabileceğini, Katılımc1 12 ise kilit paydaşların kurum sözcülüğü adına olumlu izlenimlerinin olmasının kuruma katkı sağlayacağını belirtmektedirler. 
Görüşmecilerden bir kısmı, "kilit paydaşlarla yürütülen misafirperverlik ilişkilerinde uygulayıcıların sahip olması gereken bir takım niteliklerin bu ilişkinin başarılı bir şekilde yürütülmesine katkı sağlayacağını" belirtmişlerdir: Katılımcı 8, kurumu temsil edebilmesi adına uygulayıcının, bir iletişimci olarak niteliklerinin iyi olması gerektiğini ve misafirperverliğini bu kişisel donanım ve yeteneklerine göre yürütmesi gerektiğini belirtmektedir. Katılımcı 15 uygulayıcıların kilit paydaşlarla sürdürülebilir bir ilişki kurabilmesi için, sıcak ve samimi bir ilişki kurulmasını önermektedir. Katıllımcı 16 misafirperverlik ilişkilerinde, uygulayıcıların hata payını sıfıra indirecek ve memnuniyet düzeyi yüksek planlamalar yapmaları gerektiğini vurgulamaktadır. Katılımcı 4 ise kurulacak ilişki yapısı olarak samimiyet ve dürüstlük unsurlarına dikkat çekmektedir.

Görüşmecilerden bir kısmı ise "hediyeleşme ilişkilerinde olduğu gibi etik hususlara dikkat edilmediğinde olumsuz sonuçlarla karşılaşılabileceği konusunda kaygılarını belirtmişler ve bu sebeple hedef kitle ayrımının bir çıkar ilişkine dönüşeceğini, uygulayıcıların bu kişiler için abartılı davranış ve uygulamalarda bulunabileceği ve ilerleyen süreçlerde de bir zorunluluk haline dönüşebileceği hususundaki endişelerini” paylaşmışlardır: Bu kapsamda görüşmecilerden elde edilen veriler değerlendirildiğinde, Katılımc1 14 misafirperverlik ilişkilerinde etik boyutun gözardı edilmemesi gerektiğini, Katılımc1 21 halkla ilişkiler uygulayıcılarının hedef kitle ayırmadan faaliyetlerini herkese aynı sorumlulukta yürütmesi gerektiğini, Katılımc1 9 hediyeleşme ilişkilerinde belirttiği gibi kilit paydaşlarla yürütülen bu ilişkilerin etik dışı olduğunu ve yürütülecekse de kamuya açık ve şeffaf olunması gerektiğini, Kattlımcı 18 uygulayıcıların kilit paydaşların onayını ve beğenisini almak adına ciddiyeti kaybetmemesini, Katılımcı 5 ise misafirperverlik ilişkilerinin zorunluluk gibi algılanmasından duydukları endişeleri dile getirmektedirler.

Genel olarak değerlendirildiğinde misafirperverlik Türk toplumunun karakteristik özelliklerindendir. Bu kültürel unsurun halkla ilişkiler faaliyetlerine olumlu katkıları bulunmaktadır. Ancak hediyeleşme ilişkilerinde olduğu gibi yürütülen iletişim ve ilişkinin boyutunun etik bir çerçevede olması gerekmektedir. Görüşmecilerden elde edilen veriler değerlendirildiğinde genel olarak Türk toplumunun bu karakteristik özelliklerinin halkla ilişkiler faaliyetlerinde olumlu yansımalarının olduğu kanaatinde bulundukları görülmektedir. Halkla ilişkiler uygulayıcılarının kilit paydaşlarla yürüttükleri misafirperverlik ilişkilerinde (bir organizasyonda ağıllama, basın gezileri, basın toplantılant, yemekler, kurum veya işletme ziyaretleri vb.) ise etik hususlar dikkate alınarak, planlı olarak, herhangi bir yanlış anlaşılmaya firsat vermeyecek şekilde, profesyonel anlamda bu ilişkilerin yürütülmesi gerekmektedir.

\section{Sonuç}

Halkla ilişkiler faaliyetlerinin amacına ulaşabilmesi, doğru hedef kitleye doğru mesajın verilebilmesi için ve başarılı bir şekilde yürütülebilmesi için kültür kilit rol oynamaktadır. Kişisel etki modelinin temel varsayımı kültürün tüm iletişim süreçlerinde belirleyici ve yönlendirici olduğudur. Kişisel etki modelinin uygulamalan değerlendirildiğinde kurulan iletişim, misafirperverlik ilişkileri, hediyeleşme ilişkileri, önemli günlerde kutlama veya destek olma gibi unsurların kültürün dinamikleri içerisinde yer aldığı görülmektedir.

Çalışmada akademisyenlerin kişisel görüş ve fikirlerine başvurulmuştur. Bu sebeple Nevşehir Hacıbektaş Veli Üniversitesi Etik Komisyonundan bilimsel etiğe uygunluk belgesi alınmıştır. Görüşmecilerin ifadelerine göre, kişisel etki modeli uygulamalarından önemli günlerin kutlanması, davetler ve hediyeleşme ilişkileri aracıllğıyla hem iç hem de diş paydaşlarla daha sıcak ve samimi ilişkiler kurularak kurumsal iletişimin pekiştirileceği, kurumsal kimlik ve imaj açısından olumlu katkılar sağlayacağı ortaya çıkmaktadır. Ancak elde edilen veriler değerlendirildiğinde kişisel etki modeli uygulamalarından önemli günlerin hatırlanması, davetler ve hediyeleşme ilişkilerine yönelik görüşmecilerin fikirleri alındığında, genelinin önemli günlerin hatıllanması ve davetler konusunda bir endişe duymazken, hediyeleşme ilişkilerinin doğru ve kararında yapılmadığında etik dışı bir uygulama olarak hem kuruma hem de hediye verilen insanlara zarar verebileceği düşüncesine sahip oldukları sonucuna ulaşılmaktadır.

Hediyeleşme ilişkilerine duyulan kaygı neticesinde Türk kültüründe hediyeleşme ilişkilerinin dini inanç pratikleriyle desteklendiği, hediyelerin maddi boyutundan ziyade manevi boyutunun önemli olduğu, hatırlanmanın hedef kitleyi mutlu edeceği ve hedef kitlenin zihninde olumlu bir alg1 oluşturabileceği sonucu ortaya çıkmaktadır. Görüşmecilerden elde edilen veriler çerçevesinde; hediyeleşme ilişskilerinin halkla ilişsiler uygulamalarında etkili olacağı ve çoğunlukla Batı toplumlarından farklılaşarak daha çok Doğu toplumlarıla benzerlik gösterdiği, bu duruma en önemli etkenin kültürel dinamiklerin benzerliği 
yani aile bağları, insan ilişkileri, değerler, inanç gibi unsurların önemli olduğu, Batı ile hem kültürel farklılıklar sebebiyle hem de kapitalist tüketim mantığ1 sebebiyle hediyeleşme ilişkilerinde farkl1liklar olduğu, hediyelerin maddi boyutu yüksek olduğunda kilit paydaşlarla yürütülen ilişkilerin çıkar ilişsisine evrilebileceği ve bu paydaşlar tarafindan rüşvet vb. gibi etik olmayan davranışlar olarak algilanabileceği, hediyelerin maddi değerlerinden çok manevi değerlerinin olması gerektiği gibi sonuçlarla karşılaşılmıştur.

Kişisel etki modelinin uygulamalarından misafirperverlik ilişkilerinin Türk toplumunda kültürel bir ritüel olarak değerlendirildiği bu sebeple halkla ilişkiler uygulamalarına kolayllkla entegre edildiği ve misafirlere gereken özen ve saygının gösterilmesi gerektiği hususunda görüşmecilerin büyük çoğunun hem fikir olduğu sonucuna ulaşılmaktadır. Misafirperverlik ilişkilerinin sadece ağırlanan hedef kitlenin memnuniyeti ile sınırlı kalmadığını kurumun imajını ve itibarını arttırdığı, bilinirliğini arttırdığı hususunda da birçok katıllımcı görüşlerini ifade etmiştir.

Kilit paydaşlarla yürütülen misafirperverlik ilişkilerinde, Türk toplumunda misafirperverliğin karakteristik bir özellik olmasından dolayı halkla ilişkiler faaliyetlerine olumlu katkılarının bulunacağı söylenebilmektedir. Ancak kilit paydaşlarla yürütülen bu ilişkiler profesyonel bir şekilde ve etik hususlara dikkat edilerek gerçekleştirilmelidir.

Kişisel etki modeli kapsamında elde edilen verilere göre halkla ilişkiler uygulamalarında kilit paydaşlarla birincil ilişkiler kurulmasının önemli olduğu ve faaliyetlerin başarısını olumlu etkilediği sonucuna ulaşılmıştır. Türk toplumunda halkla ilişkiler uygulayıcılarının kilit paydaşlarla birincil ilişki kurdukları ancak bu ilişkiler daha profesyonel ve sürdürülebilir bir şekilde yürütülmesi gerektiği, bu konuda uygulayıcıların henüz yeterli olmadığı ve bu sebeple etik olmayan davranışlara zemin hazırlanabileceğine ilişkin kaygılar ortaya çımaktadır.

\section{Extended Abstract}

When public relations theories are evaluated, four basic models (press agency, public information, twoway asymmetric and two-way symmetric) come to mind first, which Grunig and Hunt (1984) classified from public relations practices. However, they have come to the conclusion that this classification can vary in different countries and cultures with general principles and special practices with their studies of excellence in public relations. The personal impact model shows that culture can be determinant in public relations activities and practices can achieve different outcomes in countries with different cultures.

The personal influence model can be defined as establishing good relations between public officials, former bureaucrats, journalists who have a say, NGO executives, activists called primary stakeholder,in short, public relations practitioners who have a say in the society and successfully conducting public relations activities by benefiting from these relations when the institution needs it. Personal influence practices carried out in this context can be classified as hospitality relations, hosting, celebration of important days, conducting gift relations, and obtaining regular and up-to-date information about primary stakeholders. The fact that the personal influence model is accepted as the fifth model of public relations and especially emphasizes the cultural element has made this model tested by many researchers in different countries.

However, the clustering of the studies mostly in Asian countries has been evaluated as a criticism over time. In addition, research has been conducted that the applications of this model may also be available in countries with different cultures. Considering the work related personal influence model in Turkey it is seen that literature is quite limited. In this context, the subject of this research was determined as the evaluation of the applications of the personal influence model in public relations from the point of view of Public Relations Academics. Its main purpose is to determine whether the personal influence model is applied in Turkey and to determine how it is applied if it is applied. The basic research question created for this purpose was asked in order to determine the effects of personal influence model practices on public relations activities. The data obtained within the scope of this study is of great importance in terms of being an example of other research to be carried out with the personal influence model. 21 academics from 41 communication faculties were interviewed within the scope of the research. The academics interviewed in the study were selected according to quota sampling and purposeful sampling techniques within the scope of improbable sampling. 
A descriptive study was conducted using expert interview analysis and semi-structured interview technique with academics. Attention has been paid to the employment of academics in public relations departments. Restricting the study to only academics working at state universities and conducting e-mail interviews are the limitations of the study. The data obtained from the interviewers with the Personal Influence Model applications were divided into three categories: relationships with key stakeholders; celebrating important days, invitations and gift giving relationships; including social rituals and hospitality relations.

As a result, when the opinions of academics are evaluated, it can be stated that the practices of personal influence are compatible with Turkish culture and dynamics. Hospitality relations in Turkish culture, welcoming them in the best possible conditions, making them happy and satisfied when leaving overlap with hospitality relationships in the personal relationship model. It was concluded that establishing primary relations with key stakeholders in public relations practices is important and positively affects the success of the activities. In Turkish society, there are concerns that public relations practitioners have primary relations with key stakeholders, but these relations should be conducted in a more professional and sustainable way, that practitioners are not yet sufficient in this regard, and therefore may lead to unethical behavior. It is also concluded that celebration of important days reinforces corporate communication by establishing warm and sincere relationships with both internal and external stakeholders through invitations and gift-giving relationships and provides positive contributions in terms of corporate identity and image, but when gift giving relationships are not done correctly and properly it may harm both the institution and the people who are given gifts as an unethical practice.

\section{Kaynakça}

Akdağ, M. ve Güner Koçak, P. (2018). Bibliometric Analysis on Personal Influence Model as a Public Relations Model. B. O.Aydın, E. Şahin ve Ö. Duğan (Ed.) Public Relations and Advertising Theories: Concepts and Practices içinde (ss.13-37). Berlin: Peterlang.

Arklan, Ü. (2011). Halkla İlişskiler: Kavram, Kapsam ve İlişkili Olduğu Alanlar. M. Işık ve M. Akdağ (Ed.) Dünden Bugüne Halkla İlişkiler içinde (ss.13-48). Konya: Eğitim Akademi Yayınları.

Aziz, A. (2015). Sosyal Bilimlerde Arassterma Yöntemleri ve Teknikleri, Ankara: Nobel Yayıncillk.

Becerikli, S. Y. (2008). Ve halkla Ilişkiler Şeytann Avukatluğndan Arabuluculuğa; Bir Disiplinin Eleștirel Analizi. Ankara: Karınca Yayınları.

Creswell, J. W. (2017). Araștırma Deseni Nitel, Nicel ve Karma Yöntem Yaklaşımlar (Çev. Selçuk Beşir Demir). Ankara: Eğiten Kitap.

Göçer, K. (2017). Ahiliği Potlaç Kültürü Üzerinde Yeniden Düşünmek, SEFAD, 37: 465-476. doi.org/10.21497/sefad.328641

Grunig, J. E., Grunig, L. A., Sriramesh, K., HuangY. H. and Lyra A. (1995). Models of Public Relations in an International Setting. Journal of Public Relations Research, 7 (3), 163-186. researchgate.net/publication/249873665_Models_of_Public_Relations_in_an_International_Setting

Huang, Y .H. (2000). The Personal Influence Model and Gao Guanxi in Taiwan Chinese Public Relations, Public Relation Review, 26(2), 219-236. DOI: 10.1016 / S0363-8111 (00) 00042-4.

Karasar, N. (2019). Bilimsel Arasstrma Yöntemi Kavramlar Illkeler Teknikler (34. Bask1), Ankara: Nobel Yayinevi.

Merriam, S. B. (2018). Nitel Araştrrma Desen ve Uygulama İ̧̧in Bir Rebber (Çev. Ed. Selahattin Turan). Ankara: Nobel Yayınları.

Schriner, M. (2008). The Public Role Model in Public Relations: an Integrated Approach to Understanding Personal Influence in the Public Arena. Italy, Milan: Presented to the European Public Relations Research and Education Association.

Sriramesh, K., Kim, Y. and Takasaki, M. (1999). Public Relations in Three Asian Cultures: An Analysis. Journal of Public Relations Research, 11(4), 271-292. DOI: 10.1207 / s1532754xjprr1104_01

Taylan, A. (2015). Nitel ve Nicel Araştırmalarda Evren ve Örneklem Seçimi ve Sorunlar. B. Yıldırım (Ed.) Illetişim Arasstrrmalarnda Yöntemler Uygulama ve Ömeklerle içinde (47-83), Konya: Literatürk Academia Yayıncilik. 
Toprak, A. (2019). Türk Kültüründe Misafirperverlik ve Sofra Açmak/ Sofra Çekmek (Samsun Örneği), Mecmua Uluslararast Sosyal Bilimler Dergisi, 4(7), 74-81. doi.org/10.32579/mecmua.534041

Valentini, C. (2009). Personal Influence Model, Cultural Premises and Corruption-Understanding Societal Orientations Towards Informal Relations, Bucharest, Romania. EUPRERA 2009 Congress.

Yıldıım, A. ve Şimşek, H. (2018). Sosyal Bilimlerde Nitel Araștırma Yöntemleri. Ankara: Seçkin Yayınclık. YÖK İstatistik, https://istatistik.yok.gov.tr/ Erişim tarihi:16.10.2019. 